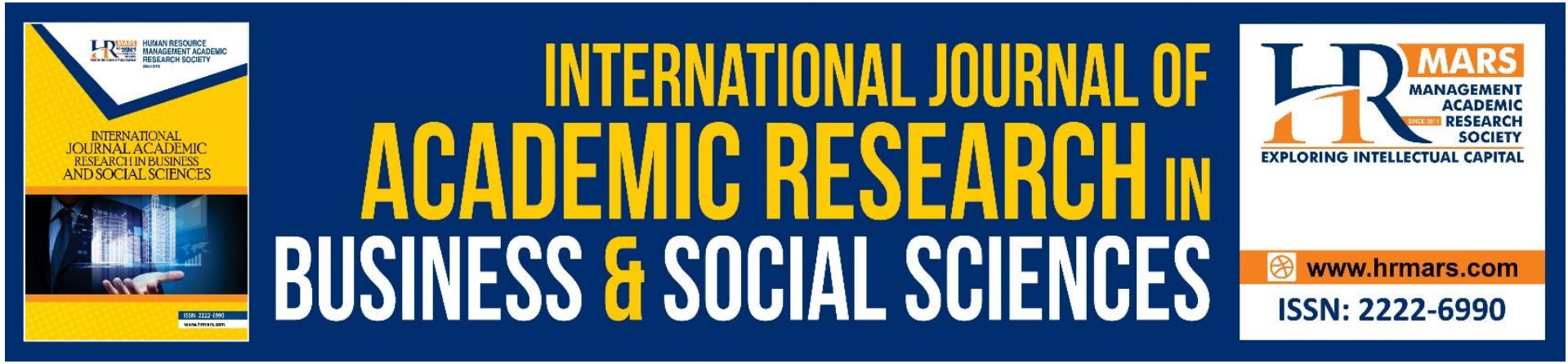

\title{
Family Environment and Coping Skills for Self-Injurious Behavior and Suicide Attempt among Adolescents
}

\section{Zurina Zaini, Ku Suhaila Ku Johari, Mohamad Isa Amat}

To Link this Article: http://dx.doi.org/10.6007/IJARBSS/v11-i9/10798

DOI:10.6007/IJARBSS/v11-i9/10798

Received: 10 July 2021, Revised: 30 July 2021, Accepted: 20 August 2021

Published Online: 14 September 2021

In-Text Citation: (Zaini et al., 2021)

To Cite this Article: Zaini, Z., Johari, K. S. K., \& Amat, M. I. (2021). Family Environment and Coping Skills for SelfInjurious Behavior and Suicide Attempt among Adolescents. International Journal of Academic Research in Business and Social Sciences, 11(9), 547-559.

\section{Copyright: (C) 2021 The Author(s)}

Published by Human Resource Management Academic Research Society (www.hrmars.com)

This article is published under the Creative Commons Attribution (CC BY 4.0) license. Anyone may reproduce, distribute, translate and create derivative works of this article (for both commercial and non-commercial purposes), subject to full attribution to the original publication and authors. The full terms of this license may be seen at: http://creativecommons.org/licences/by/4.0/legalcode

Vol. 11, No. 9, 2021, Pg. 547 - 559

Full Terms \& Conditions of access and use can be found at http://hrmars.com/index.php/pages/detail/publication-ethics 


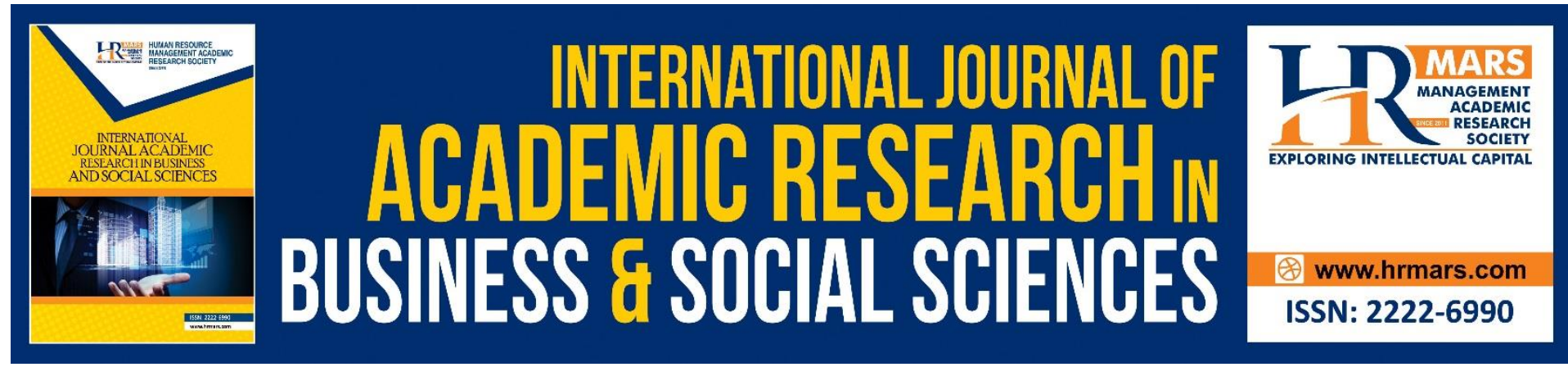

\title{
Family Environment and Coping Skills for Self- Injurious Behavior and Suicide Attempt among Adolescents
}

\author{
Zurina Zaini ${ }^{1}$, Ku Suhaila Ku Johari², Mohamad Isa Amat ${ }^{3}$ \\ 1,2Universiti Kebangsaan Malaysia, ${ }^{3}$ Universiti Sains Islam Malaysia \\ Email:suhaila@ukm.edu.my
}

\begin{abstract}
This study aims to explore how the family environment and coping skills are associated to selfinjurious behavior and suicide attemps among adolescents. This study uses a systematic literature review method. A total of 18 articles journal, published between 2012 and 2020, were referred and has been systematically analyzed. The findings indicate that parental involvement and social support have a significant influence on psychological well-being among adolescents. Coping skills are an important component of social behavior and in forming individuals with positive resilience. Resilience is a factor that can help individuals maintain psychosocial adaptation throughout stressful situations. In this study, the psychological well being of person was an important aspect that can affect adolescents' mental health. Family environmental factors are often associate with the causes of selfinjurious behaviors and suicide attempts. Family financial problems have a significant influence on the suicidal behavior of adolescents. Self-injurious behaviors as lacking coping skills is related as a self-control mechanism in situations perceived as stressful. Individuals who conceal this will suffer more stress and if the action is repeated, the risk of suicidal ideas will be induced. For future research, this study suggests conducting an experimental research design and module development related to preventon and ttreatment of suicidal phenomenom throught the identification of risk group in Malaysia.
\end{abstract}

Keywords: Family Environment, Coping Skills, Self-Injurious Behaviors, Suicide Attempts, Mental Health, Adolescents

\section{Introduction}

Adolescent is often associated with developmental stages that have crises and stress. During the COVID-19 pandemic, the number of adolescents experiencing stress and subsequently affecting mental health conditions is also increasing (Schumacher, 2021). Research conducted by Sretta et al (2021) in Nepal reported that the increasing levels of infections and uncertainty induced substantial fears and concerns, leading to stress and anxiety. This was super imposed onto lockdown restrictions, national financial issues, and a lack of physical contact with other family members and friends. The consequences of the pandemic and lockdown on the socio economic, mental health, and other aspects of Nepalese society are immense. These alarming conditions may exacerbate the suicidal rate, which is already high in that part of the world. 
Likewise, certain evidence suggests that previous epidemics and pandemics were associated with rises in suicides and suicidal behavior (John et al., 2020). However, few studies have been undertaken on the relationship between family environments, coping skills and mental health among adolescents, especially in Malaysia. The accuracy of this study's results may explain the relationship between family processes and adolescent mental health. Understanding the role of adolescent coping skills can become a foundation for improving adolescent mental well-being, with the use of family-focused interventions to address issues of mental well-being.

In addition, according to Rodriguezet et al (2014), low levels of affective family involvement and poor family functioning sush as lack of support and open communication and high levels of conflict, influence the level of thought restructuring and the ability of adolescents to obtain emotional support, as well as consumption adaptive coping skills in managing stress. The results of this study are consistent with the theory that a positive family environment facilitates the development of coping strategies (Kliewer et al., 1994), as well as the role of thought restructuring and the ability to obtain emotional support as a method of preventing and treating adolescent behavioral problems. Studies have also found that the efficiency with which coping strategies are used is associated with behavioral problems. The use of proactive coping skills may be an important prevention and intervention mechanism for solving problems caused by stress-induced negative or aggressive behaviors.

Self-injurious behavior is synonymous with Non-Suicidal Self-Injury (NSSI), Recurrent SelfMutilation (RSM), Self-Harming Behavior (SHB), or Deliberate Self-Harm (DSH), (Lieberman, 2004). By definition, NSSI has no suicidal intent. It typically involves efforts to manage unusual emotional stress that is related to feelings such as anxiety, sadness, guilt, emptiness, or separation, in order to obtain relief. NSSI is also becoming a common phenomenon and involves a variety of methods that result in physical harm but are less medically severe and, compared to suicide attempts, rarely fatal. For example, burning and cutting are used, rather than more potentially lethal methods like shooting or hanging (Pompili et al., 2015).

Meanwhile, parasuicides are a broader classification of self-harm that includes the selfdestruction of body tissues atvarious levels of intent. The attempts may display a clear intention to end one's life which is suicide attempts, no intention to end one's life (DSH), or ambiguity about ending one's own life (Chapman, Gratz \& Brown, 2005). Common parasuicide behaviors include cutting, scratching, burning, biting, bruising, and fractures. Self-injury usually includes any culturally unacceptable injury inflicted on oneself, but self-injury screening is sometimes limited to the intentional and unintentional destruction of body tissues, thus excluding certain behaviors like self-poisoning or drug overdoses (Chapman et al., 2005, cited in Matthew (2015). The focus of the study by Chapman et al (2005) was on parasuicidal behavior, which is also described as self-injurious behavior.

Discussion has focused on the issue of whether self-injurious behavior is an early ideation of suicide attempts, particularly between researchers from the UK and the US. Hawton et al (2012) argued that self-injurious behaviors, such as yelling and suicide attempts, may be two expressions of "suicidal ideation". The self-injurious behavior of the licking method is associated with a higher risk of suicide (Hawtonet al., 2015). Therefore, many countries have undertaken studies to understand the character of self-injurious behavior because it is not considered the action of a mental patient: various studies have reported it as a lack of coping skills. Thus, accurate understanding of the data can lead to the development of better-quality individual help, so they potentiallyavoid choosing suicidal acts. Studies from many countries demonstrate theculturaldifferences in the demographic character and forms of dominant 
self-injurious behavior. The relationship between self-injurious and suicidal behaviors is relevant, while many studies have focused more on the context of Western countries. The risk of any data distortion due to the character of Malaysian culture should be avoided. In fact, the Adolescent Health Survey conducted by the Ministry of Health Malaysia in 2017 showed that there had been an increase in the use of alcohol and drugs in line with increasing age. Ten percent of teenagers aged 13 to 17 had experienced a serious intention to commit suicide at some point.

\section{Research Objective and Purpose}

This study can be referred by various parties and government agencies so that the phenomenon of self-injurious behavior and suicide attempts can be swiftly addressed. This study can also serve as a basis and guide for mental health research, psychology, and counseling in order to develop proactive prevention measures and intervention modules for adolescents at high risk of self-harm and suicide attempts. The importance of strengthening the education system, especially in respect of mental health and parenting, is the right step to ensuring that the quality of human capital is not compromised in the productive age. Thus, this study aimed to explore how the family environment and coping skills are connected to self-injurious behavior and suicide attempts among adolescents.

\section{Methodology}

This study used a systematic literature review as its research design, through the qualitative method. In total, 21 articles were selected for use in writing this study. Keywords in English were used to identify articles related to the topics of the study, including the relationship between family environments, coping skills, self-harm behavior, suicide attempts and mental health. These also included "family environment", "coping skill", "strategy of coping", "nonsuicidal self-injury", "self-harm", "self-injurious behavior", "suicide"and "suicide attempt". 'Coupling' techniques were also used to connect two terms, such as "relationship between family environment and self-harm". Additional related keywords were also used to find related articles. The snowball searching method (Webster \& Watson 2002; Nurkhairina, Shahrazad \& Rahim, 2017) was also used, that is, by looking at the reference list of an article to identify more relevant articles. Based on the keywords search, the researchers found that the variables of psychological and mental health factors were often associated with selfinjurious behaviors and suicide attempts. A substantial number of related articles were searched using the search engines Google Scholar, Elsevier, and EBSCO host. Research articles and books published between 2012 and 2020 formed the basis of this literature review.

\section{Result and Discussion}

This section presents the highlights of past research on family environmental factors, coping skills and self-harming behaviors and suicide attempts. In addition, this section also discusses the relationship of self-injurious behavior as a moderator of suicide attempts. Next, several studies on mental health and psychological factors involving self-injurious behavior and suicide attempts are discussed in this concept paper.

The findings of metasynthesis in this study show that psychological well-being was the most widely stated, as it featured in eight journals and involved eight metasynthesis articles. This was followed by the mental health, which amounted to six journals and consisted of six metasynthesis articles. Next, the family relationship, family interaction and self-adaption mechanism have three journals, with three articles on metasynthesis. The last theme is 
economic status, with two journals, from which two article metasynthesis. Table 1 shows the findings in meta-synthesis.

Table 1: The Findings in Meta-Synthesis According to Theme

\begin{tabular}{|c|c|c|c|}
\hline No & Theme & Findings & Authors \\
\hline \multirow[t]{8}{*}{1} & \multirow[t]{8}{*}{$\begin{array}{l}\text { Psychological } \\
\text { well-being }\end{array}$} & $\begin{array}{l}\text { Self-resilience is essential to } \\
\text { improving individuals' cognitive } \\
\text { capacities so they can choose moral } \\
\text { behaviors that allow them to cope } \\
\text { with stress and avoid the risk of } \\
\text { suicide attempts. }\end{array}$ & $\begin{array}{l}\text { Kirtley et al, } \\
2020\end{array}$ \\
\hline & & $\begin{array}{l}\text { A relationship between low self- } \\
\text { esteem and suicidal intent. }\end{array}$ & $\begin{array}{l}\text { Siti Norma } \\
\text { Aisyah \& Salleh, } \\
2018\end{array}$ \\
\hline & & $\begin{array}{l}\text { Support received from family and } \\
\text { friends can reduce the impact of } \\
\text { psychological problems among } \\
\text { students. }\end{array}$ & Sanu et al, 2018 \\
\hline & & $\begin{array}{l}\text { Psychological factors play an } \\
\text { important role in shaping self- } \\
\text { discipline. }\end{array}$ & $\begin{array}{l}\text { Mohd Kairul et } \\
\text { al., } 2018\end{array}$ \\
\hline & & $\begin{array}{l}\text { Level of psychological well-being of an } \\
\text { individual also influence whether the } \\
\text { behavior is latent or develops to the } \\
\text { level of a suicide attempt. }\end{array}$ & Fortune, 2016 \\
\hline & & $\begin{array}{l}\text { Strategy of coping with or adapting to } \\
\text { stress that is exercised by an elusive } \\
\text { individual to solve a problem. }\end{array}$ & $\begin{array}{l}\text { Bazrafshan et al, } \\
2014\end{array}$ \\
\hline & & $\begin{array}{l}\text { Proactive coping skills improves } \\
\text { psychological well-being. }\end{array}$ & $\begin{array}{l}\text { Mahbobeh, } \\
2013\end{array}$ \\
\hline & & $\begin{array}{l}\text { High levels of stress were correlated } \\
\text { with the use of wrongful actions, } \\
\text { while the use of correct actions was } \\
\text { correlated with good psychological } \\
\text { well-being. }\end{array}$ & Yang, 2010 \\
\hline \multirow[t]{3}{*}{2} & \multirow[t]{3}{*}{ Mental health } & $\begin{array}{l}\text { An individual's thoughts and } \\
\text { behaviors are important factors that } \\
\text { contribute to self-injurious behavior. }\end{array}$ & $\begin{array}{l}\text { Kirtley et al, } \\
2020\end{array}$ \\
\hline & & $\begin{array}{l}\text { Healthy psychology can be an internal } \\
\text { force that deters and prevents one } \\
\text { from participating in acts of self-harm. }\end{array}$ & $\begin{array}{l}\text { Mohd Kairul et } \\
\text { al., } 2018\end{array}$ \\
\hline & & $\begin{array}{l}\text { The use of problem-solving actions is } \\
\text { associated with reducing the effects of } \\
\text { depression, anxiety, and psychological } \\
\text { stress. }\end{array}$ & $\begin{array}{l}\text { Mirkovic et al, } \\
2018\end{array}$ \\
\hline
\end{tabular}




\begin{tabular}{|c|c|c|c|}
\hline & & $\begin{array}{l}\text { Better coping skills lead to better } \\
\text { mental health and a higher quality of } \\
\text { life. }\end{array}$ & $\begin{array}{l}\text { Bhattacharyya } \\
\text { et al., } 2018\end{array}$ \\
\hline & & $\begin{array}{l}\text { Healthy psychology also refers to an } \\
\text { inner individual strength that can } \\
\text { prevent a person from committing } \\
\text { acts. }\end{array}$ & $\begin{array}{l}\text { Mahbobeh, } \\
2013\end{array}$ \\
\hline & & $\begin{array}{l}\text { Unhealthy coping mechanisms, their } \\
\text { mental health remained good. }\end{array}$ & Yang, 2010 \\
\hline \multirow[t]{4}{*}{3} & \multirow[t]{4}{*}{$\begin{array}{l}\text { Family } \\
\text { relationships }\end{array}$} & $\begin{array}{l}\text { The way negative parental attitudes } \\
\text { can affect learning about emotions } \\
\text { and how to manage them. }\end{array}$ & $\begin{array}{l}\text { Daniel \& Dinesh, } \\
2021\end{array}$ \\
\hline & & $\begin{array}{l}\text { Finding a balance between } \\
\text { adolescents' personal autonomy and } \\
\text { their relationships with primary } \\
\text { caregivers. }\end{array}$ & $\begin{array}{l}\text { Stewart et al., } \\
2020\end{array}$ \\
\hline & & $\begin{array}{l}\text { The involvement of the family is } \\
\text { necessary in helping to overcome the } \\
\text { child's difficult situation. }\end{array}$ & $\begin{array}{l}\text { Stewart et al., } \\
2020\end{array}$ \\
\hline & & $\begin{array}{l}\text { People displaying high-risk behaviors } \\
\text { showed psychological symptoms and } \\
\text { family dysfunction. }\end{array}$ & $\begin{array}{l}\text { Grandcierc et al, } \\
2016\end{array}$ \\
\hline \multirow[t]{3}{*}{4} & \multirow[t]{3}{*}{$\begin{array}{l}\text { Family } \\
\text { interaction }\end{array}$} & $\begin{array}{l}\text { Emotional disabilities associated with } \\
\text { external behaviors can be strongly } \\
\text { influenced by family interactions. }\end{array}$ & $\begin{array}{l}\text { Daniel \& Dinesh, } \\
2021\end{array}$ \\
\hline & & $\begin{array}{l}\text { The experiences with family members } \\
\text { as a result of insecurity and trust, as } \\
\text { well as feeling the inherent pressure } \\
\text { of the family bond. }\end{array}$ & $\begin{array}{l}\text { Waals et al., } \\
2018\end{array}$ \\
\hline & & $\begin{array}{l}\text { Family interactions, intimacy in the } \\
\text { family relationship, tolerance, } \\
\text { emotional support, parental levels of } \\
\text { mental health. }\end{array}$ & Fortune, 2016 \\
\hline \multirow[t]{3}{*}{5} & \multirow[t]{3}{*}{$\begin{array}{l}\text { Mechanism of } \\
\text { self-adaptation } \\
\text { to stress }\end{array}$} & $\begin{array}{l}\text { This condition affects the } \\
\text { development of their emotional } \\
\text { management skills, thus placing self- } \\
\text { injurious behavior as a tool with which } \\
\text { to escape intolerable influences. }\end{array}$ & $\begin{array}{l}\text { Daniel \& Dinesh } \\
\text { (2021) }\end{array}$ \\
\hline & & $\begin{array}{l}\text { The use of problem-solving actions is } \\
\text { associated with reducing the effects of } \\
\text { depression, anxiety, and psychological } \\
\text { stress. }\end{array}$ & Mirkovic, 2018 \\
\hline & & $\begin{array}{l}\text { People focused on emotions, such as } \\
\text { women and those with low levels of } \\
\text { education, tend to self-harm to } \\
\text { reduce stress. }\end{array}$ & $\begin{array}{l}\text { Bazrafshan et al, } \\
2014\end{array}$ \\
\hline
\end{tabular}




\begin{tabular}{|l|l|l|l|}
\hline 6 & $\begin{array}{l}\text { Economic } \\
\text { situation of the } \\
\text { family }\end{array}$ & $\begin{array}{l}\text { Family financial problems have a } \\
\text { significant influence on the suicidal } \\
\text { behavior of adolescents. }\end{array}$ & Tallon's, 2016 \\
\cline { 4 - 5 } & $\begin{array}{l}\text { families family finances, lax family } \\
\text { structure and relationships, parents } \\
\text { with unstable employment, and }\end{array}$ & $\begin{array}{l}\text { Hui Zhai et al, } \\
\text { incorrect parenting style. They } \\
\text { examined how these factors } \\
\text { contributed to suicidal ideation. }\end{array}$ & \\
\hline
\end{tabular}

Anuar (2016) affirmed that the family environment refers to the general pattern of interaction between the members of a family. This pattern of interaction encompasses the forms of communication and treatment always given to children, whether inside or outside the home. According to Vinacke (1969), the environment is a complex force that can influence individual behavior. Meanwhile, Moos and Moos (1976) said that the family environment is a family psychosocial environment, which describes the quality of family life and promotes open communication, conflict resolution, and good interpersonal relationships within and outside the family. Meanwhile, Plunckett et al (2000) stated that the coping strategies used by a person play a role in reducing or moderating the relationship between stress variables that exist with tension. McCubbin and McCubbin (1989) stated that a coping strategy means an effort that uses behaviors to solve a variety of demands produced by a source of stress. Meanwhile, according to Lazarus and Folkman (1984), resilience is defined as a person's way of responding to a stressful situation that he or she faces. Coping is a cognitive and behavioral effort to control, reduce, or allow external and internal desires that occur because of stressful transactions that occur.

\section{Psychological Well-Being}

The study also found that imitating self-injurious behavior, if it existed in the family history, increased the risk of suicide. Social support and the level of psychological well-being of an individual also influence whether the behavior is latent or develops to the level of a suicide attempt (Fortune, 2016). Furthermore, the study by Aisyah and Salleh (2018) showed the alarming extent of the data related to the development of suicide cases, worldwide and in Malaysia. In this study, self-harm (i.e., intention to die is uncertain) has been defined as a definition of suicidal behavior. It has been recognized that the Malaysian educational and cultural system strongly rejects self-harm and suicide. A suicide attempt can lead to the perpetrator being convicted for a crime in Malaysia. Studies have found that teenagers between the ages of 16 and 19 have the highest rates of suicidal ideation. Most previous researchers noted a relationship between low self-esteem and suicidal intent (Aini, 2001; Kelly et al., 2001; Man \& Leduc, 1995; Marcenko et al., 1999; Overholser et al., 1995; Simons \& Murphy, 1985; Sun et al., 2006).

Self-esteem is a process that is formed from early childhood experiences. The family is considered the first agent in the formation of a child's socialization. The support and guidance of a parent or primary caregiver, as well as the existence, looseness, or absence of these emotional ties in early childhood, affect all aspects of life, including the individual's manner of action when dealing with conflict. Grandcierc et al. (2016) also conducted a narrative study to observe the relationship between self-injurious and suicidal behaviors and found that people displaying high-risk behaviors showed psychological symptoms and family 
dysfunction. Families that are regarded as trustworthy and supportivefail to play a role causing self-injurious behavior, which is used as a defense mechanism to regain self-control.

\section{Mental Health}

A study by Yang (2010) involving American students and international students from Asia (Taiwan, China, and Korea) confirmed that high levels of stress were correlated with the use of wrongful actions, while the use of correct actions was correlated with good psychological well-being. The study involved 131 American and 77 Taiwanese, 53 Chinese and 50 Korean students from 90 US universities. Yang (2010) found that although Taiwanese international students used unhealthy coping mechanisms, their mental health remained good. A study by Sanu et al (2018) on coping strategies indicated that support received from family and friends can reduce the impact of psychological problems among students. However, without this form of support, students will be prone to depression, stress, and anxiety.

Previous studies have confirmed the link between coping strategies and mental health. For example, Mirkovic et al (2018) evaluated the relationship between coping strategies and mental health involving 167 adolescents aged 16 to 17 years admitted to the ward for suicide attempts. The results of the study found that there is a relationship between coping style and mental health. The use of problem-solving actions is associated with reducing the effects of depression, anxiety, and psychological stress. In fact, Bhattacharyya et al. (2018), who studied the relationship between proactive coping skills and self-injurious behavior based on previous studies, reported that better coping skills lead to better mental health and a higher quality of life.

The study by Khairul et al (2018), who conducted a content analysis study based on the topic of self-harm, stated the importance of knowing which psychological factors lead to the occurrence of self-injurious behavior. Psychological factors play an important role in shaping self-discipline. An individual may be unable to control external factors, but a healthy psychology can be an internal force that deters and prevents one from participating in acts of self-harm, such as injuring oneself. The findings of the study by Mahbobeh (2013) showed that the use of proactive coping skills improves psychological well-being. Therefore, healthy psychological development is highly important in shaping individual mental health. Healthy psychology also refers to an inner individual strength that can prevent a person from committing acts that can harm them and those around them, such as self-destructive behavior. In the worstcase, these self-harm attempts can lead to suicide attempts. Therefore, research on the psychological aspects or internal factors of individual adolescents is necessary so that this problem can be curbed and addressed at its origins. Therefore, researchers have hypothesized that proactive action can reduce suicidal ideation when an individual is faced with a challenging situation. An interesting factor, the score of a subscale: strategic planning. It was found to be higher in suicide attempts compared to controls. While self-harm does not lead to suicide, another important point to recognize about the relationship between selfharm and suicide is that the act of self-harm reduces suicidal behavior should a person become suicidal. In other words, the "practice" of repeatedly harming the body makes it easier to harm the body with suicidal intent.

\section{Family Relationships}

Children who are exposed to ineffective parenting develop inappropriate behaviors in their interpersonal relationships to support themselves during times of stress. This condition 
affects the development of their emotional management skills, thus placing self-injurious behavior as a tool with which to escape intolerable influences. Suicide attempts serve to draw attention to the strength of family ties (Daniel \& Dinesh, 2021). Thus, the role of family relationships in relation to the factors of self-harm and suicide attempts suggests that coping with insecurity, doubt and stress in family relationships influence individual behavior. Studies have found that teenagers who self-harm often have loose family ties, whether with their parents, guardians, or siblings. Adolescents hide self-injurious behavior and place such actions as autonomous. Meanwhile, parents who are aware of a change in their child oftenthink that it is a process whereby adolescents are searching for their identity, rather than linking the change to the weaknesses of family relationships.

Furthermore, self-injurious behavior is recognized as complex behavior and occurs widely in adolescence. This developmental period was expressed as having an impetus in finding a balance between adolescents' personal autonomy and their relationships with primary caregivers. When they become aware of an adolescent's self-injurious behavior, primary caregivers also experience confusion about how to act. They might suffer from feelings of guilt, fear and shame, while their negative feelings and self-evaluation can lead to oversupervision and anxiety until the control, they exert over the child's behavior also changes dramatically. More phone calls, inquiries, and observations will leave teenagers feeling overwhelmed and that their privacy is being further invaded, resulting in poorer family functioning and an increased risk of suicide. Therefore, the importance of maintaining family dynamics through a reciprocal process can disruptthe balance in the family before or after the act is discovered. Therefore, the involvement of the family is necessary in helping to overcome the child's difficult situation, but this can also result in the situation deteriorating due to the pressure of the family environment. The study found a variety of family factors were associated with self-harm and suicide attempts because of poor family environments and low levels of parental control. In fact, adolescents who tend to report weak family ties are more likely to attempt suicide (Stewart et al., 2020).

\section{Family Interaction}

Most studies support the view that a family environment that provides less emotional support to a child will lead to an increased risk of self-harm and suicide attempts. The paradigm of socialization means the way negative parental attitudes can affect learning about emotions and how to manage them. For example, studies show that emotional disabilities associated with external behaviors can be strongly influenced by family interactions that reinforce negative influences and undesirable behaviors. Therefore, most studies attempt to examine the quality of communication and social problem-solving within the families of individuals who self-injure. Parental emotions influence the development and expression of self-injurious behavior (Daniel \& Dinesh, 2021). Adolescents may find it difficult to communicate and share emotions, thoughts, and experiences with family members because of insecurity and trust, as well as feeling the inherent pressure of the family bond (Waals et al., 2018). The main concern is that parents, guardians, and teachers are unaware of the symptoms even though they exist in high-risk groups. Denial of problems also occurs between families and parents due to the influence of friends. Family interactions, intimacy in the family relationship, tolerance, emotional support, parental levels of mental health, and parental attitudes of control are factors that relate to children's self-injurious acts (Fortune, 2016). This research also suggests that studying family therapy interventions as a contribution could be an adequate method of treatment in addressing the issue of self-harm. 


\section{Mechanisms of Self-Adaptation to Stress}

Previous studies have confirmed the link between coping strategies and mental health. For example, Mirkovic et al (2018) evaluated the relationship between coping strategies and mental health involving 167 adolescents aged 16 to 17 years, who had been admitted to a ward for suicide attempts. The results of this study demonstrated a relationship between coping style and mental health. The use of problem-solving actions is associated with reducing the effects of depression, anxiety, and psychological stress. In fact, the study by Bazrafshan et al (2014) affirmed that self-injurious behavior is a strategy of coping with or adapting to stress that is exercised by an elusive individual to solve a problem. People focused on emotions, such as women and those with low levels of education, tend to self-harm to reduce stress.

However, the act of self-harm is dangerous even without a suicide attempt. It may only be a deliberate act of self-harm, such as cutting or self-immolation, to overcome strong emotional pain, anger, or frustration. Self-harm can evoke a momentary sense of calm and satisfaction, usually followed by guilt and shame, as well as the return of painful emotions. The reason for self-harm and the repetition of such acts can evoke very difficult emotions and make one feel worse, to the point of finding control difficult. It is necessary to prevent the act of self-harm from becoming one on which individuals depend through knowledge and guidance. Hence, proper stress management mechanisms would help improve mental well-being as individual people are constantly faced with the challenges of self-harm in life.

\section{Economic Situation of the Family}

Tallon's (2016) study showed that self-injurious behavior was unrelated to the family's economic situation. In fact, the researcher found that the rate of self-harm is high among adolescents of high socioeconomic status. On the contrary, family financial problems have a significant influence on the suicidal behavior of adolescents. The study of university students in China by Zhai et al (2015) also analyzed how similar participants were in terms of their families' family finances, lax family structure and relationships, parents with unstable employment, and incorrect parenting style. They examined how these factors contributed to suicidal ideation.

Meanwhile, the study by Kirtley et al (2020), which used the Internet network analysis method, indicated that an individual's thoughts and behaviors are important factors that contribute to self-injurious behavior. Although a relationship between the factors of family and friends has not been shown, manyprevious studies and researchers have confirmed the strong connection between the factors of family and friends and the issue of self-harm. Therefore, the researchers highlighted the possibility that partial variables influenced the study findings. Meanwhile, there is a relationship between Internet exposure as a contributing factor and self-injurious thoughts and behaviors. If this study is shown to be valid, the role of improving education is related to coping skills, as these help to develop individual resilience by filtering information disclosure from Internet networks. Self-resilience is essential to improving individuals' cognitive capacities so they can choose moral behaviors that allow them to cope with stress and avoid the risk of suicide attempts.

Plunckett et al (2000) stated that a person's coping strategies play a role in reducing or moderating the relationship between stress variables that exist with tension. McCubbin and McCubbin (1989) stated that a coping strategy means an effort that uses behaviors to solve a variety of demands produced by a source of stress. Meanwhile, according to Lazarus and 
Folkman (1984), resilience is defined as a way in which a person respondsto a stressful situation that he or she faces. Coping is a cognitive and behavioral effort to control, reduce, or allow external and internal desires that occur as a result of stressful transactions.

\section{Conclusion}

Based on the results of this survey of previous studies related to the phenomenon of selfinjurious behavior and suicide attempts, it can be identified as an issue that is gaining attention. Concerns about the issue have provoked discussions and attemptsto find the most effective solution. The focus of this study was on the relationship of a number of variables with the family environment and coping skills. The findings from previous studies illustrate that the family environment is essential for the development of good mental well-being. Therefore, the causes of self-harm and suicide attempts are largely associated with a weak family environment, such as ineffective parenting, and a lack of communication and emotional support. In turn, family dysfunction will create the risk of self-injurious behavior, which may extend to suicide attempts.

Various studies argue that coping strategies diversify and strengthen an individual's level of comfort when making a suicide attempt. Resilience becomes protection from social support, especially at the adolescent level. The use of problem-solving actions aims to overcome psychological stress. However, studies agree that coping skills mean an individual is capable of managing stress, while the use of negative coping strategies tends to occur when individuals are in a state of high stress. Self-injurious behavior is considered a symptom of deteriorating mental health and the use of negative coping is a strategy to overcome psychological problems. Without the support of family and friends, mental health conditions will deteriorate. The act of suicide will have a lasting effect and not go unnoticed by the community. Suicide risk assessment has been recommended for perpetrators of self-harm, although this group is not considered mentally ill. Self-injurious behavior is a mechanism that is used as self-control and when mental abilities are affected due to a high level of stress, the risk of suicide arises. The development of the phenomenon of self-injurious behavior and suicide attempts is a matter of current global concern. Demographic considerations would enable a better understanding of this phenomenon in order to identify at-risk groups.

In this study, it was observed that the frequency of self-injurious behaviors is related to the risk of suicide. The variety of methods and the duration of self-injurious behavior with a focus on aggression are considered indicative of the risk that those who perform the act will become increasingly comfortable with suicide attempts. Adolescents will grow to adulthood, which is the productive age of human capital. The rise in suicidal ideation, if not addressed and curbed, will have a major impact not only on the national economy, but also on the well-being of the population.

Secondary education offers anopportunity to strengthen human capital. Adolescents who are not made aware of right or wrong in their actions will continue their habits into adulthood. Mental health affects a person's physical health, quality of life, and productivity. Research also states that the stigma of mental illness in the community must be overcome through enlightenment so that a healthy and positive society can immediately develop. Surveys show that the severity of mental illness is a matter of great concern and expected to be the second biggest health problem affecting Malaysians, after heart disease. Therefore, the development of balanced human capital will guarantee the development of the country in terms of both economic and social well-being. 
Next, Malaysian society should become more aware of the issue, paying attention, and playing a role to overcome itto avoid the loss of the country's resources, especially in the productive level of human capital. Thus, enhancing the capacity of an effective parenting role can be diffused to amplify its importance and allow the development of positive adolescent resilience. This survey is expected to encourage all parties to take the domestic environment seriously in order to develop positive skills and curb self-injurious behavior. This would reduce the extent of the current mental health problems and the loss of human capital due to suicide.

\section{References}

Armitage, C. J., Panagioti, M., \& Abdul Rahim, W. (2015). Completed suicides and self-harm in Malaysia: A systematic review. General Hospital Psychiatry, 37(2), 153-165. https://doi.org/10.1016/j.genhosppsych.2014.12.002

Bazrafshan, M. R., Jahangir, F., Mansouri, A., \& Kashfi, S. H. (2014). Coping strategies in people attempting suicide. International Journal of High Risk Behaviors and Addiction, 3(1), e16265. https//doi.org/10.5812/ijhrba.16265

Bhattacharyya, D., Namdeo, M., \& Dwivedi, A. K. (2018). Proactive coping style and intentional self-harm: A cross-sectional study. Industrial Psychiatry Journal, 27(1), 67-72. https://doi.org/10.4103/ipj.ipj

Brown, R. C., \& Witt, A. (2019). Social factors associated with non-suicidal self injury (NSSI). Child Adolescent Psychiatry and Mental Health 13(23), https://doi.org/10.1186/s13034-019-0284-1

Daniel, M., \& Dinesh, B. (2012). Family environment expressed emotion and adolescent self-harm: A review of conceptual, empirical, cross-cultural and clinical perspectives. International Review of Psychiatry, 24(2), 106-114. https://doi.org/10.3109/09540261.2012.657613

Fortune, S., Cottrell, D., \& Fife, S. (2016). Family factors associated with adolescent self-harm: a narrative review. Journal of Family Therapy, 38(2), 226-256. https://doi.org/10.1111/1467-6427.12119

Grandclerc, S., De Labrouhe, D., Spodenkiewicz, M., Lachal, J., \& Moro, M. R. (2016). Relations between nonsuicidal self-injury and suicidal behavior in adolescence: A Systematic Review. Plos ONE, 11(4), e0153760. https://doi.org/10.1371/journal.pone.0153760

John, A., Eyles, E., Roger, T. W., Okoli, C., Schmidt, L., Arensman, E., Hawton, K., O'Connor, R. C., NavKapur, Moran, P., O'Neill, S., McGuinness, L. A., Babatunde K. O., Dekel, D., Macleod-Hall, C., Cheng, H., Julian P.T. Higgins, Gunnell, D. (2021). The impact of covid 19 pandemic on self harm and suicidal behaviour: update and living systematic review. F1000Research, 9(1097), 1-44. https://doi.org/10.12688/f1000research.25522.2

Khairul, D. Y. M., Kamaluddin, M. R., Tsuey, C. S., \& Mohamad, M. S. (2018). Prevalens dan faktor psikologikal tingkahlaku mencederakan diri tanpa niat membunuh diri: Satu tinjauan literatur. Malaysian Journal of Youth Studies, 89-113.

Mahbobeh, C. (2013). The effectiveness of problem-solving on coping skills and psychological adjustment. Procedia-Social and Behavioral Sciences, 84, 4-9.

Malkan, S. N. A., \& Amat, S. (2018). Pengetahuan dan kefahaman pelajar kolej $\begin{array}{lll}\text { terhadap niat bunuh diri. Jurnal Hadhari 10(1), 29-48 } & \end{array}$ ejournals.ukm.my/jhadhari. ISSN 1985-6830.eISSN 2550-2271.

Mirkovic, B., Labelle, R., Guilé, J. M., Belloncle, V., Bodeau, N., Knafo, A., Condat, A., BaptCazalets, N., Marguet, C., Breton, J. J., Cohen, D., \& Gérardin, P. (2015). Coping skills 
among adolescent suicide attempters: Results of a multisite study. Canadian Journal of Psychiatry. Revue Canadienne de Psychiatrie, 60(2), 1,37-S45.

Rodriguez, E. M., Donenberg, G. R., Emerson, E., Wilson, H. W., Brown, L. K., \&

Houck, C. (2014). Family environment, coping, and mental health in adolescents attending therapeutic day schools. Journal of Adolescence, 37(7), 1133-1142. https://doi.org/10.1016/j.adolescence.2014.07.012

Sanu, M. E., \& Balan, R. (2018). Pengaruh strategi daya tindak terhadap kesejahteraan psikologi pelajar miskin di luar bandar Sabah. Malaysian Journal of Youth Studies, 1-17.

Schumcher, C. (2021). How COVID-19 Has Affected Self-Harm Rates in the U.S. https://vistapineshealth.com/blog/covid-19-self-harm-increase/

Shrestha, R., Siwakoti, S., Singh, S., \& Shrestha, A. P. (2021). Impact of the COVID-

19 Pandemic on Suicide and Self-Harm among Patients Presenting to the Emergency Department of a Teaching Hospital in Nepal. PLoS ONE 16(4), e0250706. https://doi.org/10.1371/journal.pone.0250706

Stewart, S. L., Celebre, A., Hirdes, J. P., \& Poss, J. W. (2020). Risk of suicide and self-harm in kids: The development of an algorithm to identify high-risk individuals within the children's mental health system. Child Psychiatry \& Human Development, 51, 913-924. https://doi.org/10.1007/s10578-020-00968-9

Tallon, K. (2016). Mental Health Attitudes, Support Preferences, and Prevalence of Self-Harm Among Young People. Department of Psychology DBS. Dublin Business School, Dublin.

Waals, L., Baetens, I., Rober, P., Lewis, S., Van Parys, H., Goethals, E. R., \&

Whitlock, J. (2018). The NSSI family distress cascade theory. Child and Adolescent Psychiatry and Mental Health, 12(52). https://doi.org/10.1186/s13034-018-0259-7

Whitlock, J., \& Knox, K. L. (2007). The relationship between self-injurious behavior

and suicide in a young adult population. Arch Pediatric Adolescents Medician, 161(7), 634640. https//doi: 10.1001/archpedi.161.7.634

Yang, Y. T. (2010). Stress, Coping, and Psychological Well-Being: Comparison among American and Asian International Graduate from Taiwan, China, and South Korea University. [Unpublished Doctorofphilosophy.Psy.thesis], University of Kansas.

Zhai, H., Bai, B., Chen, L., Han, D., Wang, L., Qiao, Z., Qiu, X., Yang, X., \& Yang, Y.

(2015). Correlation between family environment and suicidal ideation in university students in China. International Journal of Environmental Research and Public Health, 12(2), 1412-1424. https//doi:10.3390/ijerph120201412 